\title{
Theoretical indications on the relationship between pyrogallol[4]arenes dynamics of assembling and geometry
}

\author{
Robert A. Cazar ${ }^{1,2}$, F. Javier Torres ${ }^{2,3}$
}

\begin{abstract}
Pyrogallol[4]arenes are macrocycles with high potential as building blocks for nanocapsules. We theoretically studied the dimeric precursors of 2,8,14,20-tetramethylpyrogallol[4]arene and 2,8,10,14-tetraphenylpyrogallol[4] arene to understand the dynamics of assembly of these compounds, and calculated the potential energy curves along the torsion angle of the (R-pyrogallol) CH-(R-pyrogallol) dimeric bond at the B3LYP/6-311G(d,p) level of theory. We found that the energy barriers for free rotation around the selected bond are 0.00133 Hartrees for the alkyl-substituted dimer and 0.77879 Hartrees for the aryl-substituted dimer. These values imply that the free rotation around the selected bond exists for the first dimer but not for the second one. Because the orientation of the substituent and the pyrogallol ring around this bond are likely to determine the geometry of the final structure, we propose that the alkyl-substituted compound will most likely adopt a crown-shaped geometry whereas the aryl-substituted compound will adopt a chair-shaped geometry. These predictions concur with experimental evidence, which shows that the geometry of pyrogallol[4]arenes depends on the substituents attached to them.
\end{abstract}

Keywords: Pyrogallol[4]arenes; computational chemistry; nanocapsules.

Edited by Beynor Paez $₫$ \& Alberto Acosta

1 ESPOCH, Facultad de Ciencias, Panamericana Sur Km 1.5, Riobamba, Ecuador.

2 Grupo Ecuatoriano para el Estudio Experimental y Teórico de Nanosistemas,-GETNano.

3 Grupo de Química Computacional y Teórica (QCT-USFQ), Universidad San Francisco de Quito, Diego de Robles y Vía Interoceánica, Quito 17-1200-841, Ecuador.

Received: 22-11-2013 Accepted: 25-03-2014

Published on line: 08-05-2014

Citation: Cazar RA, Torres FJ (2014) Theoretical indications on the relationship between pyrogallol[4]arenes dynamics of assembling and geometry. Universitas Scientiarum 19(2): 133-137 doi: 10.11144/Javeriana.SC19-2.tirb

Funding: Consorcio Ecuatoriano para el Desarrollo de Internet Avanzado, CEDIA.

Electronic supplementary material: NA

\section{Introducción}

Pyrogallol[4]arenes (Figure 1) are macrocycles that provide dimeric and hexameric capsules and other assemblies with an internal volume large enough to accommodate and transport a variety of molecules and ions (Gerkensmeier et al. 1999, Atwood et al. 2001, Shivanyuk \& Rebek 2001, Loustarinen et al. 2004, Maertz et al. 2010). Projected applications of these compounds include their usage as molecular filters, nano-carriers, nano-reactors and gas-storage units (Antesberger et al. 2005, Purse \& Rebek 2005, Avram \& Cohen 2006, Bassil et al. 2007, Jin et al. 2008, Dalgarno et al. 2009, Scott et al. 2009). 


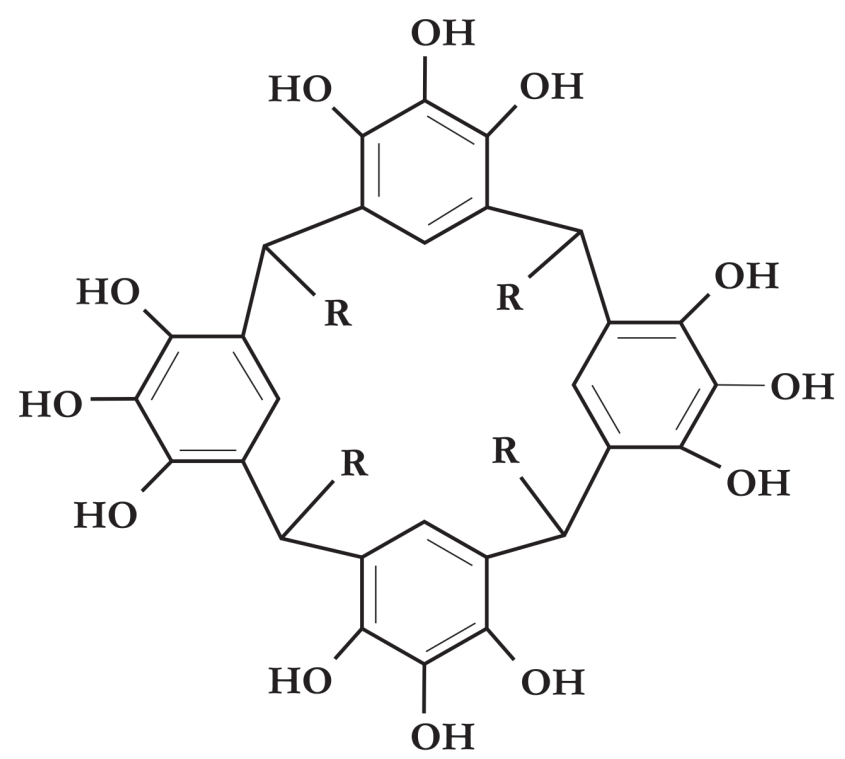

Fig. 1. A scheme of the molecular structure of a pyrogallol[4]arene. The molecule is a macrocyclic oligomer containing four pyrogallol rings and four pendant substituents denoted by $\mathrm{R}$. When $\mathrm{R}$ is an alkyl-substituent, the compound adopts a crown-shaped geometry whereas when $\mathrm{R}$ is an aryl-substituent the compound adopts a chair-like geometry.

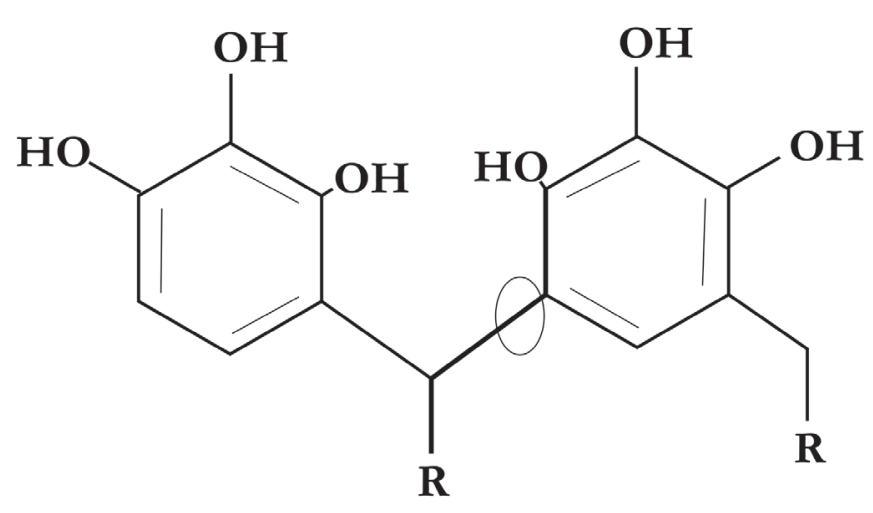

Fig. 2. A scheme of the dimer precursor of a pyrogallol[4]arene is shown. The $\mathrm{C}-\mathrm{C}$ bond that controls the geometry of the final product is highlighted. The R-C-C-C torsion angle that is gradually increased in order to obtain the potential energy curves is indicated.
Pyrogallol[4]arenes are obtained by the acidcatalyzed condensation of a pyrogallol and an aldehyde (Hoegberg 1980). Depending on the aldehyde used in the reaction, two stereoisomers are most commonly produced. A crown-shaped conformer, denoted as rccc, is obtained when alkyl aldehydes are utilized; and a chair-shaped conformer, denoted rott, is obtained when aryl aldehydes are utilized, denoted rott is obtained (Gerkensmeier et al. 2001, Zambrano et al. 2010). In this work, we performed theoretical calculations (Jensen 2007) to obtain indications on the relationship between the dynamics of assembling of alkyl and aryl substituted pyrogallol[4]arenes and their final geometries (Weilnet \& Schneider 1991, McKinlay et al. 2005). This information could be useful to project new, relevant applications of these compounds, such as their use as molecular hydrogen storage materials (Urbina et al. 2011, Gokel \& Saeedeh 2013).

\section{Materials and methods}

We calculated the potential energy curves along the torsion angle of the (R-pyrogallol) $\mathrm{CH}-$ (R-pyrogallol) bond of the dimeric precursors of 2,8,14,20-tetramethylpyrogallol[4]arene and 2,8,14,20-tetramethylpyrogallol[4] arene using density functional theory (Koch \& Holthausen 2001, Peverati \& Baldridge 2008). A scheme of the dimers is shown in Figure 2; it highlights the bond that controls macrocycle assembly. We consider that the orientations adopted by the substituent and the pyrogallol ring with respect to such bond is likely to determine the geometry of the final product.

To generate the potential energy curves, we obtained the equilibrium geometries of the dimers at the B3LYP/6-311G $(\mathrm{d}, \mathrm{p})$ level of theory and used them as starting points of the curves. We then calculated the single-point energies of the structures; this was obtained by gradually increasing the torsion angle of the selected bond in increments of five degrees in the interval of zero to 180 degrees. The structure energy versus torsion angle increment data was plotted. All the calculations were performed using a Gaussian 09 software package (Frisch et al. 2009). 


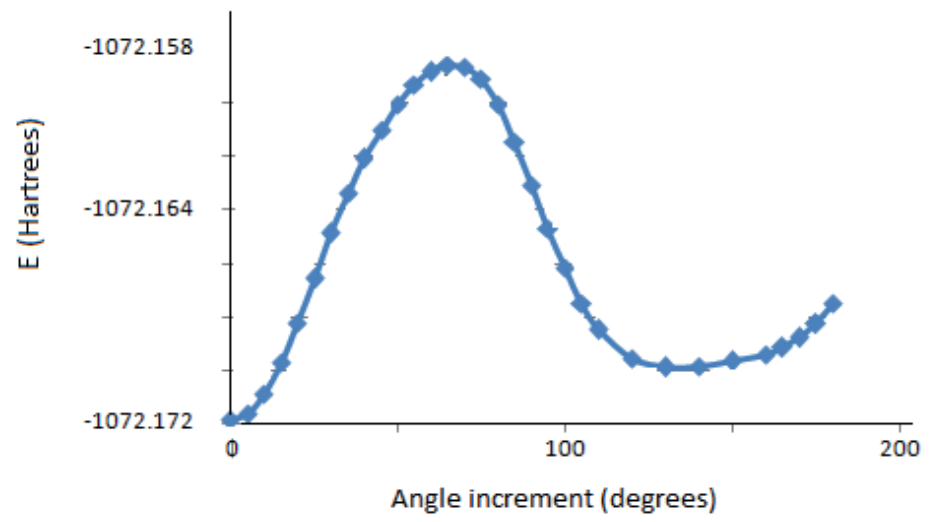

Fig. 3. The potential energy curve along the selected torsion angle of the dimer precursor of the 2,8,14,20-tetramethylpyrogallol[4]arene. The curve displays a minimum which corresponds to the energy of the dimer equilibrium geometry, and a maximum located at a 65 degree torsion angle increment. The energy difference between the maximum and minimum provides the energy barrier for free rotation around the bond that controls the geometry of the final product.

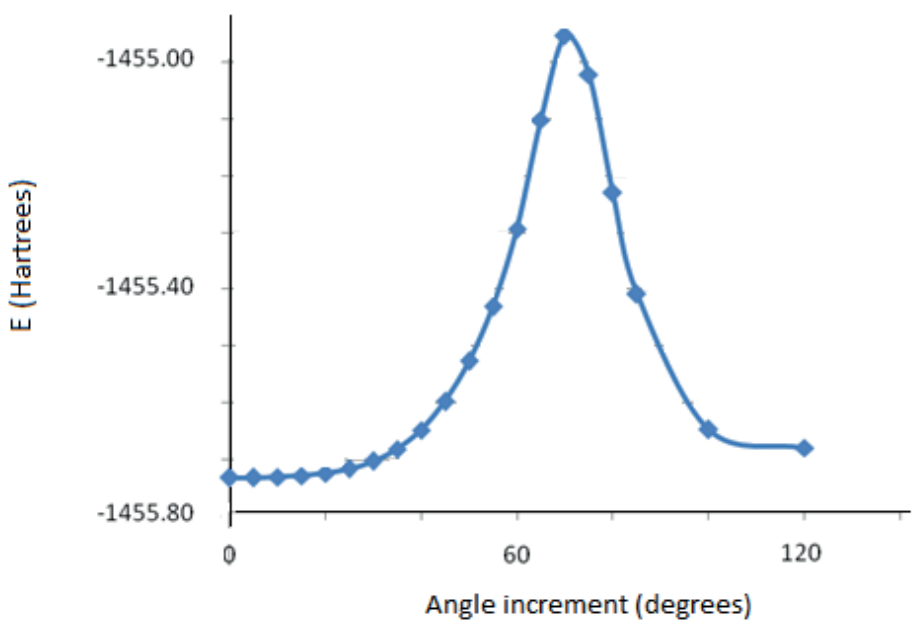

Fig. 4. The potential energy curve along the selected torsion angle of the dimer precursor of the 2,8,14,20-tetraphenylpyrogallol[4]arene. The curve displays a minimum which corresponds to the energy of the dimer equilibrium geometry, and a maximum located at a 70 degree torsion angle increment. The energy difference between the maximum and minimum provides the energy barrier for free rotation around the bond that controls the geometry of the final product.

\section{Results and discussion}

The potential energy curve along the torsion angle of the selected bond for the precursor of the 2,8,14,20-tetramethylpyrogallol[4]arene is shown in Figure 3. This curve displays a minimum which corresponds to the starting structure, that is, the dimer equilibrium geometry and a maximum located at a torsion angle increment of 70 degrees. The energy difference between these two points provides the energy barrier for free rotation around the selected bond. This barrier is calculated to be 0.00133 Hartrees $(8.3 \mathrm{kcal} / \mathrm{mol})$. This value is low enough to suggest that, when $\mathrm{R}=$ methyl, the substituent and the pyrogallol ring can freely rotate around that bond and readily reorient from their initial positions with respect to the bond as the compound is assembled. That would lead to the formation of the crown-like conformer as the final product.

The potential energy curve along the torsion angle of the selected bond for the precursor of the 2,8,14,20-tetraphenylpyrogallol[4]arene is displayed in Figure 4. In this curve the minimum corresponds to the dimer equilibrium geometry and the maximum occurs at a torsion angle increment of 70 degrees. The energy barrier for free rotation around the selected bond is calculated to be 0.77879 Hartrees (488.7 kcal/mol). This high value implies that, when $\mathrm{R}=$ phenyl, the substituent and the pyrogallol ring may not rotate around that bond and remain in their original positions with respect to the bond as the compound is assembled. That would lead to the chair-like conformer as the final product.

These predictions concur with experimental evidence that has found that the most stable products for alkyl- and aryl-substituted pyrogallol[4]arenes adopt the rcce and rett conformations, respectively (Barret et al. 2007, Thomas 2011).

\section{Conclusion}

We conducted a theoretical study of the dimers precursors of 2,8,14,20-tetra-methylpyrogallol[4] arene and 2,8,10,14-tetra-phenylpyrogallol[4]arene, and calculated the potential energy curves along the torsion angle of a selected bond of the dimers to get theoretical indications regarding the relationship 
between the dynamics of assembly and the geometry of the final products. The results suggest that alkyl substituents lead to the rccc conformation while aryl substituents would lead to the rott conformation. Such indications are in agreement with experimental evidence.

\section{Acknowledgements}

The authors wish to acknowledge the support of the Consorcio Ecuatoriano para el Desarrollo de Internet Avanzado, CEDIA, which provided the funds for this research (Grant CEPRA VI-2013-02).

\section{Conflicts of interest}

The authors declare that there are no conflicts of interest regarding the results published in this work.

\section{References}

Antesberger J, Cave GW, Ferrarelli MC, Heaven MW, Raston CL, Atwood JL (2005). Solvent-Free, Direct Synthesis of Supramolecular Nano-capsules. Chemical Communications 7:892-894

Atwood J, Barbour L, Jerga, A (2001). HydrogenBonded Molecular Capsules are Stable in Polar Media. Chemical Communications 22:2376-2377

Avram L \& Cohen Y (2006). Molecules at Close Range: Encapsulated Solvent Molecules in Pyrogallol[4] arene Hexameric Capsules. Organic Letters 8:219-222

Barret E, Dale T, Rebek, J (2007). Synthesis and Assembly of Monofunctionalized Pyrogallolarene Capsules Monitored by Fluorescence Resonance Energy Transfer. Chemical Communications 41:42244226

Bassil D, Dalgarno S, Cave G, Atwood J, Tucker S (2007) Spectroscopic investigations of adma encapsulated in pyrogallol[4]arene nanocapsules. Journal of Physical Chemistry B 111: 9088-9092

Dalgarno S, Szabo T, Siavosh-Haghighi A, Deakyne C, Adams J et al (2009) Exploring the limits of encapsulating within hexameric pyrogallol[4]arene nanocapsules. Chemical Communications 11: 1339-1341

Frisch MJ, Trucks G W, Schlegel HB, Scuseria G E, Robb MA, et al (2009) Gaussian 09

Gerkensmeier T, Iwanek W, Agena C, Fröhlich R, Kotila S et al (1999) Self-assembly of 2,8,14,20-tetraisobutyl5,11,17,23-tetrahydroxyresorc[4]arene. Journal of Organic Chemistry 9:2257-2262
Gerkensmeier T, Agena C, Iwanek W, Fröhlich R, Kotila $S$ et al (2001) Synthesis and structural studies of 5,11,17,23-tetrahydroxyresorc[4]arenes. Zeitscbrift für Naturforschung B 56:1063-1073

Gokel GW, Negin S (2013) Synthetic ion channels: From pores to biological applications. Accounts of Chemical Research 46: 2824-2833

Hogberg A (1980) Two stereoisomeric macrocyclic resorcinol-acetaldehyde condensation products. Journal of Organic Chemistry 45:4498-4500

Jensen F (2007) Introduction to Computational Chemistry. John Wiley \& Sons New York, NY, USA

Jin P, Dalgarno SJ, Barnes C, Teat SJ, Atwood JL (2008) Ion transport to the interior of metal- organic pyrogallol [4] arene nanocapsules. Journal of the American Chemical Society 130: 17262-17263

Koch W, Holthausen MA (2001) Chemist guide to density functional theory. Wiley-VCH Verlag Weinheim, Germany

Luostarinen M, Ahman A, Nissinen M, Rissanen K (2004) Ethyl pyrogall[6]arene and pyrogall[4]arene: Synthesis, structural analysis and derivatization. Supramolecular Chemistry 16:505-512

Maertz A, Thomas H, Power N, Deakyne C, Atwood J (2010) Dimeric nanocapsule induces conformational change. Chemical Communications 46:1235-1237

McKinlay R, Cave G, Atwood J (2005) Supramolecular blueprint approach to metal-coordinated capsules. Proceedings of the National Academy of Sciences 102:59445948

Peverati R, Baldridge K (2008) Implementation and performance of DFT-D with respect to basis set and functional for study of dispersion interactions in nanoscale aromatic hydrocarbons. Journal of Chemical Theory and Computation 4: 2030-2048

Purse B, Rebek J (2005) Functional cavitands: Chemical reactivity in structured environments. Proceedings of the National Academy of Sciences 102:10777-10782

Scott P, Dalgarno J, Warren J, Teat S, Atwood J (2009) Enhanced control over metal composition in mixed $\mathrm{Ga} / \mathrm{Zn}$ y $\mathrm{Ga} / \mathrm{Cu}$ coordinated pyrogallol[4]arenes nanocapsules. Chemical Communications 23:3348-3350

Shivaniyuk A, Rebek J (2001) Hydrogen-Bonded Capsules in Polar, Protic Solvents. Chemical Communications 22: 2374-2375

Thomas H (2011) Computational studies of three chemical systems. Doctorate thesis. University of MissouriColumbia

Urbina A, Saltos A, Torres FJ (2011) Estudio computacional B3LYP de la interacción del hidrógeno molecular con rccc R-Pyg[4]arenos ( $\mathrm{R}$ = metil, fluor) funcionalizados con Li+. Avances en Ciencias e Ingeniería 3:A30-A34 
Weilnet F \& Schneider H (1991) Mechanisms of macrocycle genesis. The condensation of resorcinol with aldehydes. Journal of Organic Chemistry 56:5527-5535
Zambrano C, Manzano C, Saltos A, Dueno, E, Zeller, M (2010) Síntesis de 2,8,14,20-tetra-n-butilpirogalol[4] areno y estudio computacional conformacional. Avances en Ciencias e Ingeniería 2: A22-A29
Indicios teóricos entre la relación dinámica de ensamblaje y geometría de pirogalol[4]arenos

Resumen. Los pirogalol[4]arenos son macrociclos con gran potencial como bloques de construcción de nanocápsulas. Los dímeros precursores del 2,8,14,20-tetrametilpirogalol[4]areno y del 2,8,14,20-tetrafenilpirogalol[4]areno se estudiaron teóricamente para obtener entendimiento acerca de la dinámica de ensamble de estos compuestos. Las curvas de energía potencial a lo largo del ángulo de torsión del enlace R-pirogalol) $\mathrm{CH}$-(R-pirogalol) de los dímeros han sido calculadas al nivel de teoría B3LYP/6-311G(d,p). Se encontró que las barreras de energía para rotación libre en torno al enlace seleccionado son 0.00133 Hartrees para el dímero con sustituyentes alquílicos y 0.77879 Hartrees para aquél con sustituyentes arílicos. Estos valores implican que la rotación libre en torno al enlace seleccionado es permitida para el primer dímero pero es prohibida para el segundo. Puesto que las orientaciones del sustituyente y el anillo de pirogalol en torno a este enlace posiblemente determinan la geometría de la estructura final, parece razonable proponer que el pirogalol[4]areno con sustituyentes alquílicos más probablemente adoptará una geometría de corona, mientras que el pirogalol[4]areno con sustituyentes arílicos mas probablemente adoptará una geometría de silla. Estas previsiones están en acuerdo con evidencia experimental la cual demuestra que la geometría de los pirogalol[4]arenos es dependiente del tipo de sustituyentes presentes en ellos.

Palabras clave: Pirogalol[4]arenos; química computacional; nanocápsulas.
Indícios teóricos sobre a relação entre dinâmica de montagem e geometria de pirogalol[4] arenos

Resumo. O pyrogalol [4]arenes são macrocycles com grande potencial como blocos de construção da nanocapsules. Os dímeros precursores de 2,8,14,20-tetrametilpirogalol[4]arene e 2,8,14,20-tetrafenilpirogalol[4]arene foram estudados teoricamente para obter uma compreensão sobre a dinâmica do monte destes compostos. As curvas de energia potencial ao longo do ângulo de torção da link R-pirogalol)CH-(R-pirogalol) dos dímeros foram calculados ao nível da teoria B3LYP/ 6-311G(d,p). Verificou que as barreiras de energia da rotação livre em torno do link selecionado é 0,00133 Hartrees para ao dímero com substituintes alquil e 0,77879 Hartrees para que com substituintes aril. Esses valores implicam que a livre rotação em torno da link seleccionado é permitido para o primeiro dímero mas é proibida para o segundo. Uma vez que a orientação dos substituintes e o anel de pyrogalol em torno deste link possivelmente determinar a geometria da estrutura final, parece razoável sugerir que o pyrogalol[4]arene com substituintes alquil mais provavelmente vai ter uma geometria da copa, enquanto o pyrogalol[4]arene com substituintes resíduo mais provavelmente irá ter uma geometría de cadeira. Estas previsões estão de acordo com evidências experimentais que demonstram que a geometria do pyrogalol[4]arenes é dependente do tipo de substituintes presentes nos mesmos.

Palavras-chave: Pyrogallol[4]arenos; química computacional; nano-cápsulas. 